\title{
PENGEMBANGAN MULTIMEDIA LECTORA PEMBELAJARAN TEMATIK-INTEGRATIF UNTUK PENINGKATAN NILAI KARAKTER SISWA KELAS IV SEKOLAH DASAR
}

\author{
Ervina Wahyuningsih ${ }^{1)}$ dan Ali Mustadi2) \\ 1)Universitas Muhammadiyah Surakarta dan ${ }^{2}$ Universitas Negeri Yogyakarta \\ email: epinawey@gmail.com
}

\begin{abstract}
Abstrak: Penelitian ini bertujuan untuk menghasilkan multimedia Lectora yang layak dan efektif dalam pembelajaran tematik-integratif pada subtema "Kebiasaan Makanku" untuk meningkatkan nilai karakter kelas IV SD. Penelitian dan pengembangan ini mengacu pada model pengembangan Borg \& Gall yang dimodifikasi Sukmadinata yang dikelompokkan atas tiga prosedur pengembangan: (1) studi pendahuluan; (2) pengembangan; dan (3) uji coba dan revisi. Masalah pokok penelitian adalah peningkatan nilai karakter kerja keras dan peduli lingkungan di SD Negeri 03 Jaten Karanganyar. Subjek uji coba perorangan terdiri atas 6 peserta didik, uji coba kelompok kecil 10 peserta didik, uji coba lapangan dan efektivitas 27 peserta didik. Pengumpulan data menggunakan teknik wawancara, angket, dan lembar observasi before-after. Teknik analisis data menggunakan konversi data kuantitatif ke data kualitatif dan paired sample t-test. Hasil penelitian menunjukkan multimedia yang dikembangkan berkategori "sangat baik" sehingga layak digunakan. Uji efektivitas menunjukkan persentase peningkatan karakter sebesar $75 \%$ dan $t$ hitung $<\mathrm{t}$ tabel, yaitu $-7,211<-1,710$ sehingga hal ini sangat efektif.
\end{abstract}

Kata Kunci: multimedia Lectora, pembelajaran tematik-integratif, nilai karakter

\section{DEVELOPING LECTORA MULTIMEDIA ON INTEGRATED THEMATIC LEARNING TO PROMOTE CHARACTER VALUES FOR THE FOURTH GRADE STUDENTS OF ELEMENTARY SCHOOL}

\begin{abstract}
This research and development aims to produce Lectora multimedia that are worthwhile and effective on integrated thematic learning under the sub-theme of "My Eating Habits" to promote the character values for the fourth grade students. This research and development referring to Borg \& Gall modified by Sukmadinata consisted of three developmental procedures: (1) preliminary studies; (2) development; and (3) testing and revision. The main concern of research was on improving the character values of hard work and care to the environment for the fourth grade students of SDN 03 Jaten Karanganyar. The individual subjects of try-out consisted of 6 individual learners, the small group try-out consisted of 10 students, the subjects of the field and product effectiveness try-out consisted of 27 students. Data collection instruments used were interview, questionnaire, observation sheet before-after and paired sample t-test. The results showed that Lectora multimedia product had "very good" categories, so it is worthwhile using it. The effectiveness showed a percentage of $75 \%$ increase in character and $t$ value $<t$ table, which is $-7.211<-1,710$ so it is very effective.
\end{abstract}

Keywords: multimedia of lectora, integrated-thematic learning, character values

\section{PENDAHULUAN}

Tahun 2013 dalam dunia pendidikan banyak disoroti munculnya permasalahan yang berat dalam menangani kenakalan remaja atau pembentukan karakter yang kurang maksimal sehingga muncul kebijakan untuk memberlakukan kurikulum baru yang menekankan pada pertumbuhan karakter sebagai tujuan pokok dalam pembelajaran. Kurikulum baru tersebut merupakan Kurikulum 2013 yang menggunakan pembelajaran tematik integratif. Pembelajaran tematik-integratif adalah pembelajar- 
an yang mengintegrasikan berbagai kompetensi dari berbagai mata pelajaran ke dalam berbagai tema. Ada dua hal yang diintegrasikan dalam pembelajaran tematikintegratif, yaitu integrasi sikap, keterampilan, dan pengetahuan dalam proses pembelajaran dan integrasi berbagai konsep dasar yang berkaitan. Kovalik (2002:35) menyatakan lima prinsip pembelajaran tematik-integratif yang meliputi: (1) tubuh dan fungsi otak tidak dapat dipisahkan; (2) kecerdasan adalah fungsi dari pengalaman; (3) ada banyak cara untuk menunjukan pemahaman (kecerdasan majemuk); (4) pembelajaran merupakan proses yang terdiri atas dua tahap: mencari pola yang bermakna dan membangun program yang dapat digunakan; dan (5) watak atau temperamen mempengaruhi bagaimana kita menerima, memproses, dan menghasilkan informasi. Prinsip-prinsip tersebut harus dipenuhi dalam melaksanakan pembelajaran tematik-integratif agar peserta didik mendapat pengalaman belajar yang akan mengembangkan segala potensi yang dimilikinya.

Pelaksanaan pembelajaran tematikintegratif menggunakan pendekatan scientific. Pendekatan scientific adalah sebuah pendekatan yang digunakan peserta didik memperoleh pengetahuannya melalui proses ilmiah. Schunk (2008:2) menyatakan bahwa learning is an enduring change in behavior, or in the capacity to behave in a given fashion which result from the practice or other forms of experience. Belajar merupakan perubahan perilaku yang diperoleh dari praktik secara langsung atau pengalaman. Pendekatan scientific akan memberikan pengalaman secara langsung kepada peserta didik.

Implementasi pendekatan scientific dalam pembelajaran sesuai dengan Kurikulum 2013 berdasarkan Permendikbud No.
103 Tahun 2014 tentang Pembelajaran pada Pendidikan Dasar dan Pendidikan Menengah meliputi: observing (mengamati), questioning (menanya), experimenting (mencoba), associating (menalar/mengasosiasikan), dan communicating (mengomunikasikan). Mengamati adalah kegiatan pembelajaran dimana peserta didik melakukan pengamatan secara langsung tentang konsep yang sedang dipelajarinya. Menanya adalah kegiatan menyampaikan pertanyaan, yang dapat dilakukan peserta didik atau pendidik. Kegiatan menanya bermanfaat untuk mengembangkan pertanyaan lain dan mengembangkan keterampilan berpikir kritis (Williams, 2011: 56-57). Mencoba atau mengumpulkan informasi adalah kegiatan peserta didik dengan melakukan percobaan atau mengumpulkan informasi secara langsung, terutama untuk materi atau substansi yang sesuai untuk memperoleh hasil belajar yang nyata atau autentik. Menalaradalah kegiatan pembelajaran merujuk pada kemampuan mengelompokkan beragam ide dan mengasosiasikan beragam peristiwa untuk kemudian memasukannya menjadi penggalan memori. Mengomunikasikan adalah kegiatan menyampaikan informasi kepada orang lain (Hosnan, 2013: 82). Mengomunikasikan adalah kegiatan menyampaikan hasil pengamatan, kesimpulan berdasarkan hasil analisis secara lisan, tertulis, atau media lainnya.

Pelaksanaan pembelajaran tematik-integratif dengan pendekatan scientific perlu menggunakan media pembelajaran yang dapat mendukung keberhasilan pembelajaran yang disesuaikan dengan perkembangan cara belajar peserta didik, sehingga tujuan dari pemcapaian kompetensi inti, kompetensi dasar, dan indikator pembelajaran tematik integratif dapat tercapai. Berdasarkan pemilihan media pembelajaran tersebut, secara spesifik peneliti mengguna- 
kan media pembelajaran berbasis teknologi informasi (TI) yaitu multimedia Lectora.

Kemajuan teknologi informasi banyak membawa dampak positif pada kemajuan dunia pendidikan. Keunggulan teknologi informasi yang ditawarkan bukan hanya pada faktor kecepatan untuk mendapatkan informasi namun juga fasilitas multimedia yang dapat membuat belajar lebih menarik. Sejalan dengan kemajuan teknologi informasi muncullah multimedia yang merupakan bagian dari elektronik learning. Elektonic learning dapat didefinisikan sebagai upaya menghubungkan pembelajar (peserta didik dengan sumber belajar data base, pakar/ guru, perpustakaan) yang secara fisik terpisah atau bahkan berjauhan (Sa'ud, 2008: 185). Interaktivitas dalam hubungan tersebut dapat dilakukan secara langsung (synchronous) atau tidak langsung (synchronous).

Pengajaran multimedia sangat dekat dengan pengajaran berbantuan komputer (Computer Assisted Instruction). Komputer dalam pembahasan di sini sebagai alat bantu. Komputer dapat dilengkapi untuk berbagai fungsi, misalnya tape recorder, earphones, proyektor, untuk slide dan film, layar televisi, dan keyboard, dan dapat digunakan sebagai mesin belajar atau teaching mechine. Komputer dapat memberi bermacam-macam bantuan, antara lain: (1) menyimpan bahan pelajaran yang dapat dimanfaatkan kapan saja diperlukan; (2) memberi informasi tentang berbagai referensi dan sumber-sumber serta alat audio visual yang tersedia; (3) memberi informasi tentang ruangan belajar, peserta didik dan tenaga pengajar; (4) memberi informasi tentang hasil belajar peserta didik; dan (5) menyarankan kegiatan-kegiatan belajar yang diperlukan oleh seorang peserta didik serta menilai kembali pekerjaan peserta didik pada waktunya serta memberi tugas-tugas baru untuk dikerjakan selanjutnya (Sugi- hartono, et.al, 2007: 64). Manfaat komputer yang kompleks memberikan ruang gerak bagi pendidik untuk memanfaatkannya dalam pembelajaran guna mencapai tujuan pembelajaran secara maksimal.

Peran multimedia yang sangat signifikan dalam pendidikan dalam hubungannya dengan sikap juga didukung oleh penelitian Ghuraibeh \& Alsmadi (2012:1) yang menyatakan:

"The use of multimedia applications in learning provides useful concepts for instructional content design. This study aimed to investigate the effect of design electronic curriculum and multimedia applications on acquiring $e-$ content design skills, and improving their attitudes towards e-learning. To achieve the objective of the study, the researchers developed a test to measure the efficiencies of designing electronic content and the measure of attitudes towards e-learning. The results showed that study of both courses contributed positively to the acquisition of design skills of e-content. The results revealed that there are statistical significant differences between the scores of the students in the two applications (pre and post) on the total score of the attitude measure and three areas of it."

Berdasarkan penelitian Ghuraibeh, peneliti semakin yakin akan peran multimedia dalam meningkatkan karakter peserta didik dalam pembelajaran.

Prastowo (2011:329) menyatakan bahwa multimedia merupakan bahan ajar interaktif. Bahan ajar interaktif adalah kombinasi dari dua atau lebih media (audio, teks, grafik, gambar dan video) yang oleh penggunanya dimanipulasi untuk mengendalikan perintah dan atau perilaku alami dari suatu presentasi. Oleh karena itu, dengan menggunakan bahan ajar multimedia interaktif guru dapat dengan mudah membuat manipulasi atau perintah yang disediakan dengan materi bahan ajar atau kebutuhan sehingga pembelajaran lebih menarik dan efektif. 
Multimedia pembelajaran yang dipilih, dikembangkan, dan digunakan secara tepat dan baik, akan memberikan manfaat yang sangat besar bagi para pendidik dan peserta didik. Ariani (2010:26) menyatakan bahwa secara umum manfaat penggunaan multimedia adalah (1) proses pembelajaran lebih menarik dan lebih interaktif; (2) jumlah waktu mengajar dapat dikurangi; (3) kualitas belajar peserta didik dapat ditingkatkan dan proses belajar mengajar dapat dilakukan di mana dan kapan saja; dan (4) sikap belajar peserta didik dapat ditingkatkan. Prastowo (2011:407) menyatakan tiga tujuan pokok pembelajaran dengan memakai bahan ajar berbasis komputer, yaitu: (1) untuk tujuan kognitif, dalam hal ini komputer yang menggunakan bermacam-macam tipe terminal dapat mengontrol interaksi pembelajaran, langkah dalam proses dan kalkulasi yang kompleks; (2) untuk tujuan psikomotorik, pada bagian ini terminal komputer adalah alat tentang dunia nyata yang sangat bagus untuk mengajarkan programming dan kecakapan yang serupa, bila peserta didik mau bekerja dengan terminal-terminal kerja; dan (3) untuk tujuan afektif, dalam hal ini bahan ajar berbasis komputer sangat berguna bila digunakan seperti yang diungkapkan dalam tujuan psikomotor atau digunakan untuk mengontrol bahan-bahan video. Dari kedua sumber tersebut, ada penekanan bahwa penggunaan multimedia komputer mempunyai manfaat untuk meningkatkan kompetensi peserta didik pada aspek afektif atau sikap yang sesuai dengan penelitian ini, yaitu untuk multimedia Lectora untuk meningkatkan nilai karakter peserta didik.

Fredy \& Soenarto (2013:164) menyatakan bahwa penggunaan multimedia dalam pembelajaran dapat menggabungkan unsur inovasi, kreativitas, dan hiburan, menjadikan peserta didik memiliki rasa senang, tidak jenuh menerima pelajaran, dan memudahkan guru dalam mempersiapkan materi pembelajaran. Apabila multimedia ini tersedia, maka dengan mudah peserta didik dapat memfokuskan persepsi, refleksi, penalaran, dan problem solving. Dengan berkembangnya teknologi multimedia, unsur-unsur visual, audio, dan animasi dapat dikemas menjadi satu melalui Pembelajaran Berbasis Komputer (PBK).

Mas`ud (2013:1) menyatakan bahwa Lectora adalah authoring tool untuk pengembangan konten e-learning yang dikembangkan oleh Trivantis Corporation. Lectora mampu membuat kursus online cepat dan sederhana. Pendirinya adalah Timothy D. Loudermilk di Cincinnati, Ohio, Amerika tahun 1999. Tahun 2011, Lectora memperoleh 5 penghargaan dalam bidang produk elearning inovatif, authoring tool, tool presentasi terbaik, dan teknologi e-learning terbaik sehingga wajar lebih dari 50 perusahaan atau instansi di dunia memilih Lectora. Program Lectora tergolong masih baru dalam dunia pendidikan sehingga peneliti merasa perlu mengembangkan multimedia Lectora dapat diterapkan dalam dunia pendidikan, khususnya dalam pembelajaran tematik integratif untuk meningkatkan nilai karakter.

Mas`ud (2013:1-2) menjelaskan cakupan yang ada dalam program Lectora, antara lain seperti berikut. Pertama, Fly-

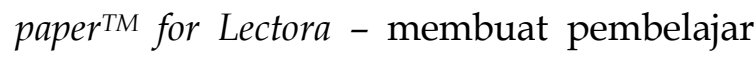
lebih kreatif dan melibatkannya dengan menambah animasi flash, transisi dan efek spasial.Kedua, Camtasia ${ }^{\circledR}$ for Lectora - membuat tutorial profesional dengan mudah meng-capture video, animasi flash atau software desain 3D sehingga akan lebih menyenangkan dalam mengedit video, audio, transisi, dan lain-lain. Ketiga, Snagit ${ }^{\circledR}$ for Lectora - meng-capture apa yang di desktop untuk membuat image, yang dilengkapi 
dengan callout, dan lain-lain. Keempat, produk tambahan (Add-ons), yaitu Lectora Integrator for Microsoft PowerPoint. Dengan menambahkan Lectora Integrator, pengguna dapat secara langsung mengubah presentasi pada Power Point menjadi Lectora. Multimedia yang sudah di-convert menjadi bentuk single file (.exe) dapat dibuka pada komputer yang mempunyai aplikasi (1) Processor Intel 1.5 GHZ; (2) 1 GB RAM untuk Lectora Inspire; (3) 900MB hard drive kosong; (4) Microsoft Windows XP, Windows Vista, atau Windows 7; (5) Agen Help membutuhkan Flash Player 8.0 atau atasnya; (6) Mocrosoft Internet Explorer 6.0 ke atas, Firefox 1.0 ke atas, dan safari 1.2 ke atas, dan Google Chrome; (7) Lectora Inspire juga membutuhkan Microsoft Direct X.9 atau terbaru untuk Camtasia, Microsoft.NET Framework 3.5 SP1 untuk Flypaper, dan Adobe Flash Player version 9.0.115.0; (8) Images: TIF, GIF, JPG, BMP, PNG, WMF, EMF, IPIX; (9) Audio: WMA, WAV, MID, RMI, AU, MP3, AIFF, FLV; (10) ASF (streaming audio oleh Microsoft) atau RM (Streaming Real Audio); (11) Video: WMV, FLV, AVI, MOV, MPG, MPEG, RM, RAM, MP4, ASF, RM (Streaming Real Audio); (12) Documents: RTF, TXT; dan (13) Lain-lainnya: Shockwave, SWF, Java, Javascript, ASP, JSP, PHP, ColdFusion.

Mas`ud (2013:2-3) menyatakan, keunggulan-keunggulan Lectora sebagai berikut. Pertama, Lectora dapat digunakan untuk membuat website, konten e-learning interaktif, dan presentasi produk atau profil perusahaan. Kedua, fitur-fitur yang disediakan Lectora inspire sangat memudahkan pengguna pemula untuk membuat multimedia (audio dan video) pembelajaran. Ketiga, bagi seorang guru atau pendidik, keberadaan Lectora dapat memudahkan membuat media pembelajaran. Keempat, template Lectora cukup lengkap. Kelima, Lec- tora menyediakan media library yang sangat membantu pengguna. Keenam, Lectora sangat memungkinkan penggunanya untuk mengonvermasi presentasi Microsoft PowerPoint ke konten e-learning. Ketujuh, konten yang dikembangkan dengan perangkat lunak Lectora dapat dipublikasikan ke berbagai output seperti HTML5, single file executable (exe), CD-ROM, maupun standar e-learning, seperti SCORM dan AICC. Dengan melihat keunggulan multimedia Lectora, sangat pantas jika multimedia tersebut diterapkan dalam pembelajaran di sekolah, dalam aspek materi pembelajaran (isi), aspek strategi (pembelajaran), dan aspek kualitas teknis guna meningkatkan kompetensi peserta didik khususnya dalam meningkatkan nilai karakter.

Palopo (2010:116-117), dalam tesis yang berjudul "Pengembangan Multimedia Pembelajaran Sains yang Humanistik di Sekolah Dasar," menyebutkan bahwa produk multimedia yang dikembangkan terbukti signifikan layak dan efektif dalam mengintegrasikan nilai humanistik. Fanny (2013:8) menyatakan bahwa kelebihan multimedia interaktif adalah dapat menggabungkan berbagai macam media dan dapat digunakan untuk pembelajaran mandiri atau klasikal sehingga peserta didik dengan berbagai tingkatan kemampuan dapat menggunakannya tanpa merasa kesulitan karena dilengkapi dengan petunjuk penggunaan. Multimedia interaktif ini menggunakan model sajian tutorial yang berfungsi memberikan tutorial layaknya seorang pendidik. Di samping itu, multimedia interaktif ini sangat praktis dikarenakan menggunakan sistem autorun dan file berbentuk exe sehingga dapat diputar di komputer mana pun dengan spesifikasi tertentu tanpa harus menginstal terlebih dahulu. 
Berdasarkan penelitian pengembangan di atas dan menyoroti permasalahan mulai lunturnya nilai karakter peserta didik dan maraknya pemberitaan kenakalan remaja dan berbagai kelebihan multimedia dalam pembelajaran, maka peneliti melakukan pengembangan multimedia Lectora dalam pembelajaran tematik integratif pada subtema "Kebiasaan Makanku" untuk meningkatkan nilai karakter kerja keras dan peduli lingkungan. Dengan dikembangkannya multimedia ini, diharapkan pendidik dapat lebih inovatif memanfaatkan teknologi untuk meningkatkan tujuan pembelajaran, khususnya dalam peningkatan nilai karakter.

\section{METODE}

\section{Jenis Penelitian}

Jenis penelitian ini adalah penelitian dan pengembangan atau Research and Developement (R\&D). Pengembangan dilakukan mengacu pada model pengembangan Borg \& Gall. Ada sepuluh langkah dalam penelitian dan pengembangan model Brog \& Gall (1983:775), yaitu: (1) penelitian pendahuluan dan mengumpulkan informasi; (2) perencanaan penelitian; (3) pengembangan produk awal; (4) melakukan uji coba terbatas produk awal; (5) melakukan revisi produk utama; (6) melakukan uji coba lapangan utama; (7) melakukan revisi terhadap produk operasional; (8) melakukan uji coba lapangan produk operasional; (9) melakukan revisi terhadap produk final; dan (10) mendiseminasi dan mengimplementasikan produk. Langkah-langkah tersebut disederhanakan ke dalam tiga prosedur. Prosedur pengembangan yang digunakan dalam penelitian ini adalah prosedur pengembangan Borg \& Gall yang dimodifikasi oleh Sukmadinata (2008:189). Akan tetapi, tahap diseminasi produk tidak dapat dilaksanakan karena keterbatasan waktu dan biaya. Pro- sedur pengembangan tersebut, meliputi: (1) studi pendahuluan; (2) pengembangan produk; dan (3) uji coba produk, revisi dan finalisasi. Tahap studi pendahuluan terdiri atas studi pustaka dan analisis kebutuhan (survei lapangan dan wawancara), dan pengembangan produk. Tahap pengembangan produk terdiri atas validasi produk. Tahap pengujian terdiri atas uji coba perorangan dan revisi, uji coba kelompok kecil dan revisi, dan uji coba kelompok lapangan dan revisi serta tahap finalisasi dilakukan untuk menguji efektivitas produk.

\section{Desain Uji Coba Produk}

Ada dua tahapan dalam uji coba produk, yaitu uji coba expert dan uji coba lapangan. Uji coba expert terdiri uji ahli atas materi dan isi serta uji ahli produk. Uji coba lapangan terdiri atas uji coba perorangan, uji coba kelompok kecil, dan uji coba lapangan (operasional produk) serta uji efektivitas produk. Subjek coba pada uji coba terbatas ini dipilih 6 peserta didik yang mempunyai kemampuan beragam: 2 tinggi, 2 sedang, dan 2 rendah; uji coba kelompok kecil dipilih 10 peserta didik yang mempunyai kemampuan beragam juga; dan uji lapangan serta efektivitas terdiri atas 27 peserta didik didik kelas IV SDN 03 Jaten Karanganyar. Uji efektivitas dilakukan dengan menggunakan desain penelitian eksperimen. Sugiyono (2009:415) menyatakan bahwa eksperimen dapat dilakukan dengan membandingkan keadaan sebelum dan sesudah (before-after) diberi perlakuan. Dalam bentuk gambar, desain yang digunakan tersebut tampak seperti pada Gambar 1.

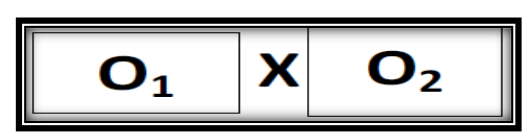
Gambar 1. Desain Eksperimen Before- After (Sugiyono, 2009: 415)


Subjek coba pada uji pendahuluan terdiri atas dua validator ahli, yaitu (1) ahli materi dan instrumen serta ahli media (produk); (2) guru kelas IV SDN 03 Jaten Karanganyar sebagai validator praktisi. Uji utama dan efektivitas merupakan peserta didik kelas IV di SDN 03 Jaten Karanganyar dengan menggunakan teknik simple random samplin.

\section{Teknik Pengumpulan Data}

Pengumpulan data dilakukan dengan teknik wawancara (analisis kebutuhan), angket, dan observasi before-after karakter. Wawancara digunakan untuk studi pendahuluan tentang kebutuhan pendidik di lapangan. Angket digunakan untuk melakukan penilaian produk multimedia Lectora oleh ahli pada uji validasi sebelum di lapangan dan praktisi pendidikan yang dilakukan setelah uji coba produk pada pembelajaran, baik uji perorangan, kelompok kecil, maupun uji lapangan. Observasi karakter dengan before-after digunakan untuk mengamati perubahan karakter karena penelitian ini berkenaan dengan perilaku manusia, proses kerja, gejala-gejala alam, dan bila responden yang diamati tidak terlalu besar. Dari data hasil observasi before-after karakter dapat dihitung persentase peningkatan karakter, kemudian dilihat tingkat efektivitasnya serta dapat dihitung signifikansi efektivitasnya dengan uji SPSS paired sample t-test.

\section{Teknik Analisis Data}

Teknik analisis data untuk pengembangan produk ini menggunakan teknik data kualitatif, data kuantitatif, dan data kelayakan produk yang dihasilkan. Teknik yang digunakan untuk menganalisis data hasil wawancara ini adalah analisis model interaktif (interactive model of analysis). Ada tiga komponen analisis yang meliputi: re- duksi data, sajian data, dan penarikan kesimpulan. Teknik analisis data yang digunakan untuk menilai kelayakan produk adalah teknik analisis data kuantitatif dengan menggunakan rumus berikut.

$$
X=\frac{\sum X}{N}
$$

Keterangan :

$$
\begin{aligned}
& \mathrm{X} \quad=\text { mean/rata-rata } \\
& \sum \mathrm{X} \quad=\text { jumlah seluruh skor } \\
& \mathrm{N} \quad=\text { banyaknya subjek } \\
& \text { (Sugiyono, 2009: } 49 \text { ) }
\end{aligned}
$$

Skor rata-rata yang diperoleh kemudian diubah menjadi nilai dengan kriteria skala lima dengan kategori pilihan tanggapan, yaitu Sangat Baik (5), Baik (4), Cukup Baik (3), Kurang Baik (4), dan Sangat Kurang Baik (1). Menurut Sukardjo (2010: 101), skor yang diperoleh kemudian dikonversikan menjadi data kualitatif skala lima (data interval). Konversi yang dilakukan terhadap data kualitatif mengacu pada

\begin{tabular}{|c|c|c|}
\hline $\begin{array}{c}\text { Data } \\
\text { Kuantitatif }\end{array}$ & Rentang & $\begin{array}{c}\text { Data } \\
\text { Kualitatif }\end{array}$ \\
\hline 5 & $X>X i+1,80$ Sbi & $\begin{array}{l}\text { Sangat } \\
\text { Baik }\end{array}$ \\
\hline 4 & $\begin{array}{l}X i+0,60 \text { Sbi }<X \leq X i+ \\
1,80 S b i\end{array}$ & Baik \\
\hline 3 & $\begin{array}{l}X \mathrm{i}-0,60 \mathrm{Sbi}<\mathrm{X} \leq \mathrm{Xi}+ \\
0,60 \mathrm{Sbi}\end{array}$ & Cukup \\
\hline 2 & $\begin{array}{l}X i-1,80 \mathrm{Sbi}<X \leq X \mathrm{X}- \\
0,60 \mathrm{Sbi}\end{array}$ & Kurang \\
\hline 1 & $X \leq X i-1,80$ Sbi & $\begin{array}{l}\text { Sangat } \\
\text { Kurang }\end{array}$ \\
\hline
\end{tabular}
rumus konversi, seperti pada Tabel 1.

Tabel 1. Konversi Data Kuantitatif ke Data Kualitatif Skala Lima untuk Kategori Kelayakan Produk

Keterangan:

$\mathrm{X} \mathrm{i} \quad=$ Rerata ideal

$=\frac{1}{2}($ skor $\max +$ skor $\min )$

Sbi = Simpangan baku ideal 


\section{$=\frac{1}{6}($ skor $\max +$ skor $\min )$ \\ $\mathrm{X}=$ Skor aktual/ skor yang diperoleh}

Data hasil uji efektivitas yang berupa data eksperimen hasil observasi before-after karakter dapat dilihat melalui: (1) menentukan kategori yang berdasarkan rentang skor dari persentase peningkatan karakter pada lembar observasi; dan (2) data beforeafter dianalisis menggunakan paired t-test related atau uji t berpasangan.

Rumus statistik yang digunakan untuk mencari persentase:

$$
P=\frac{f}{N} x 100 \%
$$

Keterangan:

$$
\begin{array}{ll}
\mathrm{P} & =\text { angka persentase } \\
\mathrm{F} & =\text { frekuensi yang sedang dicari } \\
& \text { persentasenya } \\
\mathrm{N} & =\text { Number of Case }
\end{array}
$$

(Sudijono, 2004)

Kemudian, data tersebut diinterpretasikan secara kualitatif ke dalam 5 tingkatan:

$$
\begin{array}{ll}
81 \%-100 \% & =\text { sangat efektif } \\
61 \%-80 \% & =\text { efektif } \\
41 \%-60 \% & =\text { cukup efektif } \\
21 \%-40 \% & =\text { kurang efektif } \\
0 \%-20 \% & =\text { tidak efektif }
\end{array}
$$

Pembuktian signifikansi perbedaan before-after perlu diuji secara statistik dengan t-test sampel berpasangan yang ditunjukkan rumus sebagai berikut (Sugiyono, 2009:422).

$$
t=\frac{X_{1}-X_{2}}{\sqrt{\frac{X_{1}^{2}}{N_{1}}+\frac{X_{2}^{2}}{N_{2}}-2 r\left[\frac{S_{1}}{\sqrt{n_{1}}}\right]\left[\frac{S_{2}}{\sqrt{n_{7}}}\right]}}
$$

Keterangan:

$X_{1}$ : rata-rata sampel 1 (sebelum/observasi sebelum diterapkan produk)
$X_{2}$ : rata-rata sampel 2 (sesudah/observasi sesudah diterapkannya produk)

$s_{1}$ : simpangan baku sampel 1

$s_{2}$ : simpangan baku sampel 2

$S_{1}^{2}$ : varian sampel 1

$S_{2}^{2}$ : varian sampel 2

$\mathrm{r}$ : korelasi antardua kelompok

Untuk membuktikan signifikansi perbedaan pembelajaran dengan menggunakan multimedia Lectora sebelum dan sesudah observasi, dapat menggunakan software SPSS, dalam penelitian ini menggunakan SPSS 22. Analisis menggunakan SPSS yang dilihat adalah nilai $\mathrm{p}$ (probabilitas) yang ditunjukkan oleh nilai sig (2-tailed). Aturan keputusan yang berlaku adalah, jika nilai sig > 0,05 maka $\mathrm{H}_{0}$ diterima, sebaliknya jika nilai sig $<0,05$ maka $\mathrm{H}_{0}$ ditolak.

\section{HASIL DAN PEMBAHASAN}

\section{Hasil Pengembangan Produk}

\section{Studi Pendahuluan}

Tahap studi pendahuluan terdiri atas dua tahap, yakni: mengumpulkan informasi dan melakukan penelitian awal serta penyusunan instrumen. Dalam mengumpulkan informasi dan melakukan penelitian awal dilakukan tiga proses kegiatan, yakni: studipustaka, wawancara analisis kebutuhan dan observasi, dan penyusunan produk. Studi pustaka adalah kegiatan mengumpulkan beberapa kajian teori yang akan digunakan sebagai dasar proses penelitian dan pengembangan. Kegiatan studi lapangan meliputi pengumpulan data berkenaan dengan perencanaan dan keberhasilan pelaksanaan pembelajaran tematik integratif dalam kebermaknaan multimedia guna peningkatan nilai karakter peserta didik. Pengumpulan data wawancara dan pengamatan kegiatan pembelajaran di SDN 03 Jaten Karanganyar. Berdasarkan hasil wawancara dengan guru kelas IV dapat disimpul- 
kan bahwa guru masih kesulitan dalam mendapatkan multimedia yang sesuai dengan Kurikulum 2013, khususnya untuk meningkatkan nilai karakter peserta didik.

Berdasarkan hasil studi pustaka dan studi lapangan terlihat bahwa: (1) belum adanya multimedia interaktif yang sesuai dengan Kurikulum 2013; (2) guru masih kesulitan dalam menerapkan Kurikulum 2013 dengan menggunakan multimedia sehingga umumnya hanya menggunakan buku panduan saja; (3) guru membutuhkan media pembelajaran yang bisa menyampaikan pembelajaran lebih praktis dan efektif. Dapat disimpulkan bahwa pengembangan multimedia pembelajaran tematik-integratif Kurikulum 2013 untuk SD kelas IV masih sangat diharapkan dan diperlukan untuk memaksimalkan pencapaian hasil belajar peserta didik dari berbagai ranah kompetensi peserta didik, khususnya dalam peningkatan nilai karakter yang merupakan Kompetensi Inti I dan II dalam kurikulum 2013. Oleh karena itu, peneliti mengembangkan produk berupa multimedia Lectora dalam pembelajaran tematik integratif pada subtema "Kebiasaan Makanku" untuk meningkatkan nilai karakter kelas IV SD, dimana nilai karakter yang dikembangkan adalah nilai kerja keras dan peduli lingkungan serta pelaksanaannya di SDN 03 Jaten Karanganyar. Langkah-langkah pengembangannya meliputi: (1) menetapkan materi pokok yang dikembangkan; (2) rumusan materi pembelajaran (menuliskan kompetensi inti, kompetensi dasar dan indikator keberhasilan) yang sesuai dengan peningkatan nilai karakter kerja keras dan peduli lingkungan; (3) pembuatan naskah flowchart dan storyboard; (4) pengumpulan semua materi yang dibutuhkan dalam menyusun produk multimedia Lectora; (5) pembuatan multimedia Lectora yang sudah diconvert dalam bentuk $C D$ yang di dalam- nya terdapat 6 materi pembelajaran, latihan soal dan permainan edukatif serta yang terpenting adalah integrasi nilai karakter kerja keras dan peduli lingkungan dalam materi tersebut.

\section{Hasil Validasi Produk}

Deskripsi produk awal tersusun dari: (1) strategi pembelajaran; (2) alur pemrograman; (3) bentuk tampilan produk: tampilan pembuka dan home, layar input user name, halaman inti atau menu utama, halaman materi tiap pembelajaran, tampilan KD-Indikator-Tujuan Pembelajaran.

Produk yang telah dikembangkan kemudian divalidasi oleh ahli materi pembelajaran dan ahli produk. Validasi multimedia Lectora oleh ahli materi didasarkan pada pengambilan keputusan untuk meningkatkan kualitas multimedia pembelajaran yang dikembangkan dilihat dari aspek isi dan aspek pembelajaran. Aspek isi materi yang dikemas tidak sekedar bersifat untuk mengembangkan aspek kognitif, tetapi juga sesuai dengan tujuan pengembangan multimedia ini, yaitu untuk mengembangkan aspek nilai karakter atau sikap. Sikap yang dimaksud dalam penelitian ini disesuaikan dengan subtema yang dibawa, yaitu nilai kerja keras dan peduli lingkungan. Hasil penilaian dari ahli materi dapat dilihat pada Tabel 2.

\section{Tabel 2. Hasil Validasi Ahli Materi}

\begin{tabular}{|c|c|c|c|}
\hline No. & Indikator & $\begin{array}{c}\text { Skor } \\
\text { Rata-rata }\end{array}$ & Kategori \\
\hline $\mathrm{A}$ & Aspek Isi & 4,80 & $\begin{array}{c}\text { Sangat } \\
\text { Baik }\end{array}$ \\
\hline B & $\begin{array}{c}\text { Aspek } \\
\text { Pembelajaran }\end{array}$ & 4,71 & $\begin{array}{l}\text { Sangat } \\
\text { Baik }\end{array}$ \\
\hline & $\begin{array}{l}\text {-rata dari total } \\
\text { skor }\end{array}$ & 4,76 & $\begin{array}{l}\text { Sangat } \\
\text { Baik }\end{array}$ \\
\hline
\end{tabular}

Produk multimedia Lectora yang dikembangkan telah divalidasi oleh ahli ma- 
teri dinyatakan "Layak Digunakan" dengan rincian penilaian seperti Tabel 2. Aspek Isi, yaitu materi yang terintegrasi pada nilai kerja keras dan peduli lingkungan pada subtema "Kebiasaan Makanku" sesuai dengan kompetensi inti, KD, kejelasan materi, dan keruntutan menunjukkan kategori rata-rata skor 4,80 "sangat baik" sehingga "layak digunakan". Aspek pembelajaran, yaitu sesuai Tabel 2 pencapaian rata-rata skor 4,71 juga menunjukkan kategori "sangat baik", sehingga "layak digunakan". Rata-rata perolehan validasi oleh ahli materi mencapai skor 4,76 dengan kategori "sangat baik", sehingga dinyatakan bahwa media Lectora "layak digunakan".

Hasil validasi ahli media (produk) tentang materi pembelajaran yang dikembangkan di dalam RPP, yang dinilai berdasarkan aspek ketepatan, kedalaman, dan kecukupan materi pembelajaran disajikan dalam Tabel 3.

Berdasarkan Tabel 3, terdapat 22 item penilaian yang berkaitan dengan kelayakan multimedia Lectora, dengan perolehan total skor 103 , rata-rata skor 4,68, termasuk kategori "sangat baik", sehingga multimedia "layak digunakan".

\section{Hasil Uji Coba Produk Uji Coba Perorangan}

Uji coba perorangan dilaksanakan dengan jumlah 6 peserta didik untuk melaksanakan pembelajaran tematik integratif dengan menggunakan multimedia Lectora pada subtema "Kebiasaan Makanku" yang terintegrasi nilai kerja keras dan peduli lingkungan. Data hasil uji coba perorangan ini diperoleh dari hasil angket oleh pendidik. Lembar angket digunakan untuk mengukur kelayakan multimedia guna peningkatan nilai karakter peserta didik. Hasil penilaian uji coba perorangan dapat dilihat pada Tabel 4 .
Tabel 3. Hasil Validasi Ahli Media

\begin{tabular}{|c|c|c|}
\hline No. Aspek yang Dinilai & Skor & Kategori \\
\hline $\begin{array}{l}\text { 1. Kejelasan sasaran } \\
\text { (target audience) }\end{array}$ & 5 & Sang \\
\hline 2. Kejelasan narasi & 4 & Baik \\
\hline 3. Musik pengiring & 4 & Baik \\
\hline 4. Tampilan video & 5 & Sangat baik \\
\hline 5. Tampilan gambar & 5 & Sangat baik \\
\hline 6. Penempatan tombol & 5 & Sangat baik \\
\hline 7. Keterbacaan teks & 4 & Baik \\
\hline 8. Jenis huruf & 5 & Sangat baik \\
\hline 9. Ukuran huruf & 4 & Baik \\
\hline 10. Komposisi warna & 5 & Sangat baik \\
\hline 11. Tampilan gambar & 5 & Sangat baik \\
\hline 12. Tampila & 5 & Sangat baik \\
\hline $\begin{array}{l}\text { 13. Kemenarikan tam- } \\
\text { pilan }\end{array}$ & 5 & aik \\
\hline $\begin{array}{l}\text { 14. Konsistensi penyaji- } \\
\text { an }\end{array}$ & 4 & Poil \\
\hline 15. Konsistensi navigasi & 5 & Sangat baik \\
\hline 16. Konsist & 5 & Sangat baik \\
\hline $\begin{array}{l}\text { 17. Interaksi peserta di- } \\
\text { dik dengan media }\end{array}$ & 5 & Sangat baik \\
\hline 18. Pengaturan animasi & 4 & \\
\hline $\begin{array}{l}\text { 19. Kemudahan peng- } \\
\text { gunaan }\end{array}$ & 5 & Sangat baik \\
\hline $\begin{array}{l}\text { 20. Kesesuaian umpan } \\
\text { balik }\end{array}$ & 4 & Baik \\
\hline 21. Efisiensi setiap slide & 5 & Sangat baik \\
\hline $\begin{array}{l}\text { 22. Pembabakan setiap } \\
\text { materi }\end{array}$ & 5 & Sangat baik \\
\hline Total Skor & 103 & \\
\hline $\begin{array}{l}\text { Skor rata-rata } \\
\text { aspek } \\
\text { pembelajaran }\end{array}$ & 4,68 & \\
\hline Nilai & 4,68 & Sangat baik \\
\hline
\end{tabular}

\section{Tabel 4. Skor Uji Coba Perorangan}

\begin{tabular}{|c|c|c|c|}
\hline No. & Indikator & $\begin{array}{c}\text { Skor } \\
\text { rata-rata }\end{array}$ & Kategori \\
\hline $\mathrm{A}$ & $\begin{array}{l}\text { Aspek } \\
\text { Pemb }\end{array}$ & 4,53 & $\begin{array}{c}\text { Sangat } \\
\text { Baik }\end{array}$ \\
\hline B & $\begin{array}{l}\text { Aspek Strategi } \\
\text { Pembelajaran }\end{array}$ & 4,39 & $\begin{array}{l}\text { Sangat } \\
\text { Baik }\end{array}$ \\
\hline $\mathrm{C}$ & $\begin{array}{l}\text { Aspek Kualitas } \\
\text { Teknik }\end{array}$ & 4,57 & $\begin{array}{l}\text { Sangat } \\
\text { Baik }\end{array}$ \\
\hline & $\begin{array}{l}\text { Total Skor } \\
\text {-rata dari total sko }\end{array}$ & $\begin{array}{c}85,49 \\
4,76 \\
\end{array}$ & Sangat Ba \\
\hline
\end{tabular}


Hasil analisis data angket pendidik pada uji coba terbatas dari aspek materi pembelajaran, strategi pembelajaran, dan kualitas teknis penggunaan multimedia Lectora dengan jumlah 19 item mencapai total skor 85,49 , rata-rata skor mencapai 4,50, sehingga termasuk kategori penilaian "sangat baik". Oleh karena itu, multimedia Lectora "layak digunakan". Walaupun layak digunakan, akan tetapi untuk diuji keefektifannya diperlukan uji kelompok kecil dan uji lapangan untuk memperbaiki nilai pada uji coba perorangan.

\section{Uji Coba Kelompok Kecil}

Hasil uji coba kelompok kecil dengan jumlah subjek penelitian sebanyak 10 peserta didik menggunakan multimedia yang sudah diperbaiki dari uji coba perorangan. Hasil penilaian pendidik dari uji coba kelompok kecil dapat dilihat pada Tabel 5.

Tabel 5. Skor Uji Coba Kelompok Kecil

\begin{tabular}{cccc}
\hline No. & Indikator & $\begin{array}{c}\text { Skor rata- } \\
\text { rata }\end{array}$ & Kategori \\
\hline A & $\begin{array}{l}\text { Aspek Materi } \\
\text { Pembelajaran }\end{array}$ & 4,75 & Sangat Baik \\
B $\begin{array}{l}\text { Aspek Strategi } \\
\text { Pembelajaran }\end{array}$ & 4,65 & Sangat Baik \\
C $\begin{array}{l}\text { Aspek Kualitas } \\
\text { Teknik }\end{array}$ & 4,60 & Sangat Baik \\
\hline $\begin{array}{c}\text { Total Skor } \\
\text { Rata-rata dari total } \\
\text { skor }\end{array}$ & 88,60 & \\
\hline
\end{tabular}

Hasil analisis data angket pendidik pada uji coba kelompok kecil dari aspek materi pembelajaran, strategi pembelajaran, dan kualitas teknis penggunaan multimedia Lectora dengan jumlah 19 item mencapai total skor 88,60 , rata-rata skor mencapai 4,67 sehingga termasuk kategori penilaian "sangat baik". Oleh karena itu, multimedia Lectora "layak digunakan". Pada uji kelompok kecil rata-rata skor kelayakan mengalami peningkatan dari skor uji coba perorangan sebanyak $\pm 0,17$. Walaupun layak digunakan, tetapi untuk diuji kelayakan dan keefektifan multimedia Lectora. Oleh karena itu, perlu uji lapangan dengan subjek penelitian sebanyak 27 peserta didik. Sebelum uji lapangan, peneliti perlu memperbaiki multimedia sesuai hasil penilaian pada uji kelompok kecil yang mempunyai skor kurang.

\section{Uji Coba Lapangan}

Hasil uji coba kelompok lapangan dengan jumlah subjek penelitian sebanyak 27 peserta didik menggunakan multimedia yang sudah diperbaiki dari uji coba kelompok kecil. Hasil penilaian pendidik dari uji coba lapangan dapat dilihat pada Tabel 6 .

\section{Tabel 6. Skor Uji Coba Lapangan}

\begin{tabular}{|c|c|c|c|}
\hline No. & Indikator & $\begin{array}{c}\text { Skor } \\
\text { rata-rata }\end{array}$ & Kategori \\
\hline A & $\begin{array}{l}\text { Aspek Materi } \\
\text { Pembelajaran }\end{array}$ & 4,77 & $\begin{array}{l}\text { Sangat } \\
\text { Baik }\end{array}$ \\
\hline B & $\begin{array}{l}\text { Aspek Strategi } \\
\text { Pembelajaran }\end{array}$ & 4,58 & $\begin{array}{l}\text { Sangat } \\
\text { Baik }\end{array}$ \\
\hline C & $\begin{array}{l}\text { Aspek Kualitas } \\
\text { Teknik }\end{array}$ & 4,83 & $\begin{array}{l}\text { Sangat } \\
\text { Baik }\end{array}$ \\
\hline & Total Skor & 89,7 & \\
\hline \multicolumn{2}{|c|}{$\begin{array}{c}\text { Rata-rata dari total } \\
\text { skor }\end{array}$} & 4,7 & $\begin{array}{l}\text { Sangat } \\
\text { Baik }\end{array}$ \\
\hline
\end{tabular}

Hasil analisis data angket pendidik pada uji coba lapangan dari aspek materi pembelajaran, strategi pembelajaran, dan kualitas teknis penggunaan multimedia Lectora dengan jumlah 19 item mencapai total skor 89,7 . Rata-rata skor mencapai 4,70, sehingga termasuk kategori penilaian "sangat baik". Oleh karena itu, multimedia Lectora "layak digunakan". Pada uji lapangan rata-rata skor kelayakan mengalami peningkatan dari skor uji coba kelompok kecil sebesar $\pm 0,03$.

Dari uji lapangan selain di dapat skor kelayakan multimedia Lectora, peneliti juga mengobservasi atau mengamati perubahan 
nilai karakter pada peserta didik dengan menggunakan lembar observasi before-after nilai karakter. Dalam penelitian ini, perubahan karakter yang diamati adalah nilai kerja keras dan peduli lingkungan.

\section{Uji Efektivitas}

Uji efektivitas dilaksanakan setelah produk disempurnakan berdasarkan hasil uji coba perorangan dan uji coba kelompok kecil. Uji efektivitas dilaksanakan menggunakan desain penelitian eksperimen before-after observation rating scale nilai karakter. Signifikansi perbedaan skor lembar observasi karakter peserta didik sebelum dan setelah menggunakan multimedia Lectora yang dikembangkan, perlu diuji secara statistik menggunakan uji t berpasangan.

Before-after observation ini dilakukan dengan mengamati tiga komponen kerja keras dan peduli lingkungan, yaitu kemampuan merespons sikap orang lain, kemampuan untuk mengontrol perilaku diri, dan pemahaman akan sikap peduli lingkungan. Peserta didik yang menunjukkan ketiga aspek tersebut secara utuh mendapatkan skor 4, jika menunjukkan 2 aspek mendapatkan skor 3, jika menunjukkan 1 aspek mendapatkan skor 2, dan jika tidak menunjukkan ketiga aspek sama sekali, maka mendapatkan skor 1. Tabel 7 merupakan hasil beforeafter observation karakter nilai kerja keras dan peduli lingkungan kelas IV SDN 03 Jaten Karanganyar.

Hasil before dan after menunjukkan sebanyak 21 peserta didik mengalami peningkatan nilai karakter atau dapat dihitung secara persentase didapat $75 \%$ peserta didik mengalami peningkatan nilai karakter. Selain itu, sebanyak 6 peserta didik tidak mengalami peningkatan atau dengan kata lain sebanyak $25 \%$ tidak mengalami peningkatan atau mengalami keajegan. Persentase sebesar $75 \%$ apabila diinterpretasi- kan secara kualitatif dikategorikan efektif karena berada pada rentang $61 \%-80 \%$.

Tabel 7. Hasil Data before-after Observation

\begin{tabular}{|c|c|c|c|}
\hline No. & Inisial & $\begin{array}{c}\text { Before } \\
\text { Observation }\end{array}$ & $\begin{array}{c}\text { After } \\
\text { Observation }\end{array}$ \\
\hline 1. & $\mathrm{AR}$ & 3 & 4 \\
\hline 2. & $\mathrm{AP}$ & 2 & 4 \\
\hline 3. & $\mathrm{AT}$ & 3 & 4 \\
\hline 4. & $\mathrm{AO}$ & 3 & 4 \\
\hline 5. & DB & 4 & 4 \\
\hline 6. & $\mathrm{BD}$ & 3 & 4 \\
\hline 7. & MR & 2 & 3 \\
\hline 8. & AY & 3 & 4 \\
\hline 9. & $\mathrm{RV}$ & 4 & 4 \\
\hline 10. & RA & 2 & 4 \\
\hline 11. & NC & 3 & 4 \\
\hline 12. & NN & 2 & 3 \\
\hline 13. & NP & 2 & 4 \\
\hline 14. & $\mathrm{MN}$ & 2 & 4 \\
\hline 15. & $\mathrm{KH}$ & 3 & 3 \\
\hline 16. & KS & 3 & 4 \\
\hline 17. & IR & 3 & 4 \\
\hline 18. & GP & 3 & 4 \\
\hline 19. & GL & 2 & 3 \\
\hline 20. & FR & 3 & 4 \\
\hline 21. & FM & 4 & 4 \\
\hline 22. & BA & 4 & 4 \\
\hline 23. & LA & 3 & 3 \\
\hline 24 & AS & 3 & 3 \\
\hline 25. & $\mathrm{AF}$ & 3 & 4 \\
\hline 26. & WS & 3 & 4 \\
\hline \multirow[t]{3}{*}{27.} & ZA & 3 & 4 \\
\hline & Jumlah & 78 & 102 \\
\hline & $\begin{array}{l}\text { Rata- } \\
\text { rata }\end{array}$ & 2,89 & 3,78 \\
\hline
\end{tabular}

Hasil data before-after observation nilai karakter pada tabel 7, kemudian direduksi ke dalam penghitungan statistik uji $t$ dengan SPSS 22. Hasil perhitungan paired samplet-test data before-after tersebut dirangkum dalam Tabel 8. 
Tabel 8. Rangkuman Uji t

\begin{tabular}{ccc}
\hline & Before Obs. & After Obs. \\
\hline$\sum X$ & 78 & 102 \\
$\bar{X}$ & 2,89 & 3,78 \\
Std. & 0,64051 & 0,42366 \\
Deviation & & \\
$\begin{array}{c}\text { Std.Error } \\
\text { Mean }\end{array}$ & 0,12327 & 0,08153 \\
Correlation & 0,331 & 0,331 \\
$t_{\text {hitung }}$ & \multicolumn{2}{c}{$-7,211$} \\
$t_{\alpha} 0,05$ & $-1,746 \mathrm{~s} / \mathrm{d}+1,746$ \\
\hline
\end{tabular}

Untuk membuat keputusan apakah perbedaan signifikan atau tidak, maka harga $t$ hitung dibandingkan dengan harga $t$ tabel dengan dk n-2 $=25$, yaitu $-7,211$ dengan taraf signifikansi 5\%. Hipotesis yang diuji adalah:

Ho: Efektivitas peningkatan nilai karakter sesudah menggunakan multimedia Lectora dalam pembelajaran tematik integratif pada subtema "Kebiasaan Makanku" kelas IV SD Negeri 03 Jaten Karanganyar lebih kecil atau sama dengan sebelum menggunakan multimedia Lectora.

Ha: Efektivitas peningkatan nilai karakter sesudah menggunakan multimedia Lectora dalam pembelajaran tematik integratif pada subtema "Kebiasaan Makanku" kelas IV SD Negeri 03 Jaten Karanganyar lebih besar sebelum menggunakan multimedia Lectora.

Hasil analisis menunjukkan nilai $t$ hitung adalah $-7,211$. Nilai $t$ tabel untuk $d k$ 25 pada taraf signifikansi 0,05 adalah -1,71 sampai $+1,71$. Karena nilai $\mathrm{t}$ hitung berada di luar daerah penerimaan $\mathrm{H}_{0}$, maka $\mathrm{H}_{0}$ ditolak dan Ha diterima, yaitu ada perbedaan yang signifikan antara nilai rata-rata karakter kerja keras dan peduli lingkungan peserta didik sebelum tindakan dengan nilai rata-rata karakter kerja keras dan peduli lingkungan sesudah dilakukan tindak- an. Berdasarkan data terlihat bahwa ratarata nilai after pada penilaian karakter lebih tinggi dari rata-rata nilai before. Oleh karena itu, berdasarkan hasil before-after dinyatakan secara signifikan mengalami peningkatan nilai karakter kerja keras dan peduli lingkungan. Kesimpulannya, bahwa multimedia Lectora secara signifikan efektif dalam peningkatan nilai karakter kerja keras dan peduli lingkungan dalam pembelajaran tematik integratif pada subtema "Kebiasaan Makaku" kelas IV SDN 03 Jaten Karanganyar.

\section{Revisi Produk}

Revisi produk dilaksanakan berdasarkan hasil dan saran dari proses validasi materi, produk, uji coba perorangan, dan uji coba kelompok kecil. Revisi berdasarkan hasil validasi materi terlihat pada Tabel 9.

Uraian revisi pada Tabel 9 sebagai bahan untuk revisi produk multimedia Lectora yaitu: (1) menambahkan KI-KD, dan tujuan pembelajaran; (2) menyertakan integrasi nilai pada tiap pembelajaran; (3) ukuran teks diperbesar; dan (4) menggunakan bahasa yang baku sesuai EYD. Menu tiap pembelajaran sebelum direvisi terlihat Gambar 2 (sebagai contoh pada pembelajaran $1)$.

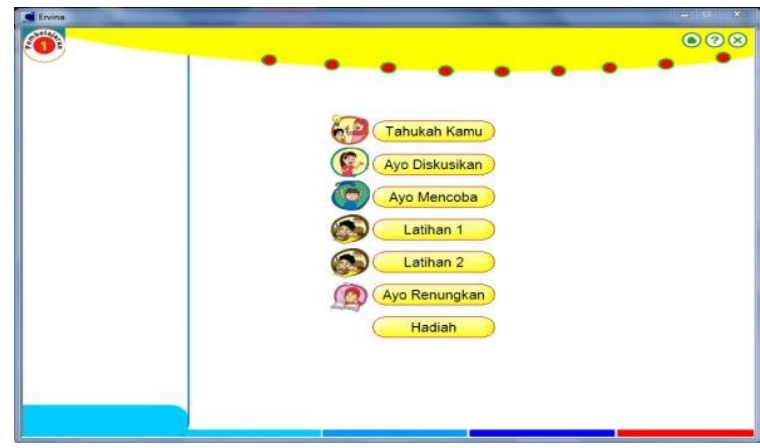

Gambar 2. Slide Menu Pembelajaran Multimedia Lectora sebelum Direvisi 
Tabel 9. Revisi dari Validasi Materi

\begin{tabular}{|c|c|c|c|}
\hline To. & $\begin{array}{c}\text { Bagian } \\
\text { yang salah }\end{array}$ & $\begin{array}{c}\text { Jenis } \\
\text { Kesalahan }\end{array}$ & $\begin{array}{c}\text { Saran } \\
\text { Perbaikan }\end{array}$ \\
\hline 1. & $\begin{array}{l}\text { Pembelaja } \\
\text { ran } 1-5\end{array}$ & $\begin{array}{l}\text { Belum me- } \\
\text { nyertakan KD- } \\
\text { Indikator dan } \\
\text { Tujuan } \\
\text { Pembelajaran }\end{array}$ & $\begin{array}{l}\text { Setiap pem- } \\
\text { belajaran di- } \\
\text { sertakan KD- } \\
\text { Indikator- } \\
\text { Tujuan Pem- } \\
\text { belajaran } \\
\text { yang rumus- } \\
\text { annya tepat. }\end{array}$ \\
\hline & $\begin{array}{l}\text { Pembelaja } \\
\text { ran 1-6 }\end{array}$ & $\begin{array}{l}\text { Belum } \\
\text { menyertakan } \\
\text { secara menye- } \\
\text { luruh untuk } \\
\text { integrasi nilai } \\
\text { yang sesuai } \\
\text { dengan } \\
\text { materi. }\end{array}$ & $\begin{array}{l}\text { Nilai yang da- } \\
\text { pat diintegra- } \\
\text { sikan pada } \\
\text { multimedia } \\
\text { Lectora harus } \\
\text { ada disetiap } \\
\text { pembelajaran, } \\
\text { bahkan harus } \\
\text { dimaksimal- } \\
\text { kan. }\end{array}$ \\
\hline 3. & $\begin{array}{l}\text { Pembelaja } \\
\text { ran 1- } \\
\text { evaluasi } \\
\text { soal }\end{array}$ & $\begin{array}{l}\text { Teks jangan } \\
\text { terlalu kecil } \\
\text { sehingga } \\
\text { membuat } \\
\text { pembaca ku- } \\
\text { rang nyaman } \\
\text { dalam mem- } \\
\text { baca. }\end{array}$ & $\begin{array}{l}\text { Semua ukur- } \\
\text { an font dise- } \\
\text { suaikan se- } \\
\text { hingga tidak } \\
\text { terlalu kecil, } \\
\text { serta jangan } \\
\text { biarkan ba- } \\
\text { nyak ruang } \\
\text { kosong pada } \\
\text { multimedia } \\
\text { Lectora. }\end{array}$ \\
\hline 4. & $\begin{array}{l}\text { Pembela- } \\
\text { jaran } 1\end{array}$ & $\begin{array}{l}\text { Pada hadiah } \\
\text { ada campuran } \\
\text { bahasa asing } \\
\text { yang tidak } \\
\text { baku. }\end{array}$ & $\begin{array}{l}\text { Gunakan } \\
\text { bahasa Indo- } \\
\text { nesia yang } \\
\text { baik dan be- } \\
\text { nar. }\end{array}$ \\
\hline 5. & $\begin{array}{l}\text { Pembelaja } \\
\text { ran 6/ La- } \\
\text { tihan soal }\end{array}$ & $\begin{array}{l}\text { Latihan soal } \\
\text { kurang me- } \\
\text { narik }\end{array}$ & $\begin{array}{l}\text { Latihan soal } \\
\text { dibuat game } \\
\text { yang variatif } \\
\text { supaya lebih } \\
\text { menarik. }\end{array}$ \\
\hline
\end{tabular}

Multimedia Lectora yang telah diperbaiki dilengkapi dengan KI-KD-Tujuan Pembelajaran yang dirangkum pada tombol "kompetensi", sedangkan integrasi nilai ditambahkan tombol baru, yaitu "integrasi nilai" sehingga peserta didik dapat membuka secara khusus dan jelas nilai apa yang wajib mereka pelajari. Lihat Gambar
3, untuk slide menu Home (sebagai contoh pada pembelajaran 1).

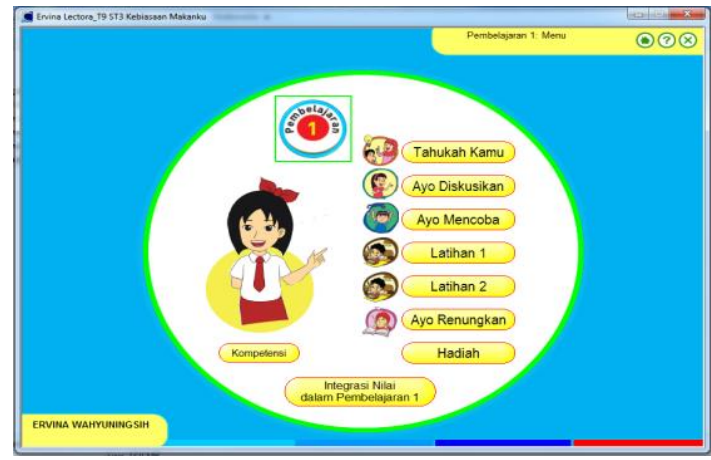

Gambar 3. Menu Pembelajaran setelah Dilakukan Revisi

Revisi berdasarkan hasil validasi media (produk) dapat dilihat pada Tabel 10.

Rangkuman dari revisi berdasarkan hasil validasi ahli produk di atas secara umum adalah pada keruntutan tombol pengatur kemunculan slide, unsur gambar setiap materi diperjelas, musik pengiring disesuaikan dengan peserta didik dan materi baik pengaturan tinggi-rendah suara dan jenis lagu. Gambar 4 menunjukkan tampilan multimedia Lectora sebelum direvisi.

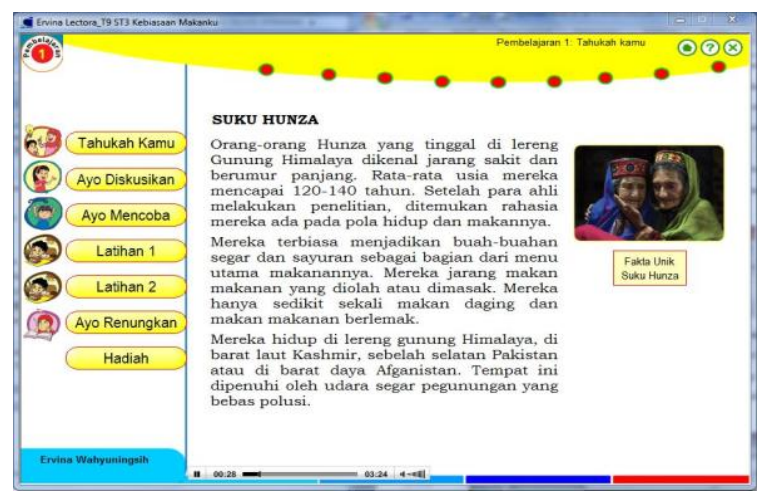

\section{Gambar 4. Slide Multimedia Lectora sebelum Direvisi}

Pada slide gambar 4, pada tombol di bawah gambar kurang jelas sehingga perlu tombol tambahan sehingga user atau peserta didik dapat lebih mudah dalam menggunakan multimedia Lectora tanpa dipandu oleh pendidik. Revisi berdasarkan saran 
ahli media (produk) dapat dilihat pada Gambar 5.

Tabel 10. Revisi dari Validasi Produk

\begin{tabular}{|c|c|c|c|}
\hline No. & $\begin{array}{c}\text { Bagian } \\
\text { yang salah }\end{array}$ & $\begin{array}{c}\text { Jenis } \\
\text { Kesalahan }\end{array}$ & $\begin{array}{c}\text { Saran } \\
\text { Perbaikan }\end{array}$ \\
\hline 1. & $\begin{array}{l}\text { Pembelajar- } \\
\text { an } 1\end{array}$ & $\begin{array}{l}\text { Tombol pe- } \\
\text { tunjuk ku- } \\
\text { rang ko- } \\
\text { munikatif }\end{array}$ & $\begin{array}{l}\text { Sertakan tom- } \\
\text { bol pemberita- } \\
\text { huan yang le- } \\
\text { bih jelas untuk } \\
\text { mengoperasi- } \\
\text { kan multime- } \\
\text { dia Lectora. }\end{array}$ \\
\hline 2. & $\begin{array}{l}\text { Pembelajar- } \\
\text { an } 1\end{array}$ & $\begin{array}{l}\text { Karena } \\
\text { gambar } \\
\text { terpisah } \\
\text { sehingga } \\
\text { kurang } \\
\text { jelas }\end{array}$ & $\begin{array}{l}\text { Gambar se- } \\
\text { baiknya diga- } \\
\text { bung supaya } \\
\text { teks narasi le- } \\
\text { bih jelas. }\end{array}$ \\
\hline 3. & $\begin{array}{l}\text { Musik } \\
\text { pengiring }\end{array}$ & $\begin{array}{l}\text { Musik pe- } \\
\text { ngiring ku- } \\
\text { rang lem- } \\
\text { but }\end{array}$ & $\begin{array}{l}\text { Diganti yang } \\
\text { lebih lembut. }\end{array}$ \\
\hline 4. & $\begin{array}{l}\text { Pembelajar- } \\
\text { an } 4\end{array}$ & $\begin{array}{l}\text { Materi ayo } \\
\text { cermati } \\
\text { petunjuk } \\
\text { tidak jelas }\end{array}$ & $\begin{array}{l}\text { Perjelas petun- } \\
\text { juk pengerjaan } \\
\text { pada materi } \\
\text { tersebut. }\end{array}$ \\
\hline 5. & $\begin{array}{l}\text { Pembelajar- } \\
\text { an } 5\end{array}$ & $\begin{array}{l}\text { Materi ayo } \\
\text { lakukan } \\
\text { petunjuk } \\
\text { tidak jelas }\end{array}$ & $\begin{array}{l}\text { Perjelas petun- } \\
\text { juk pengerjaan } \\
\text { pada materi } \\
\text { tersebut. }\end{array}$ \\
\hline 6. & $\begin{array}{l}\text { Lebar tam- } \\
\text { pilan }\end{array}$ & $\begin{array}{l}\text { Kurang } \\
\text { memenuhi } \\
\text { layar PC }\end{array}$ & $\begin{array}{l}\text { Tampilan la- } \\
\text { yar multime- } \\
\text { dia Lectora di- } \\
\text { buat selebar } \\
\text { PC. }\end{array}$ \\
\hline 7. & $\begin{array}{l}\text { Pembelajar- } \\
\text { an } 6\end{array}$ & $\begin{array}{l}\text { Tidak be- } \\
\text { rupa ma- } \\
\text { teri jadi } \\
\text { kurang se- } \\
\text { suai de- } \\
\text { ngan judul }\end{array}$ & $\begin{array}{l}\text { Pembelajaran } \\
6 \text { diganti de- } \\
\text { ngan latihan } \\
\text { soal. }\end{array}$ \\
\hline
\end{tabular}

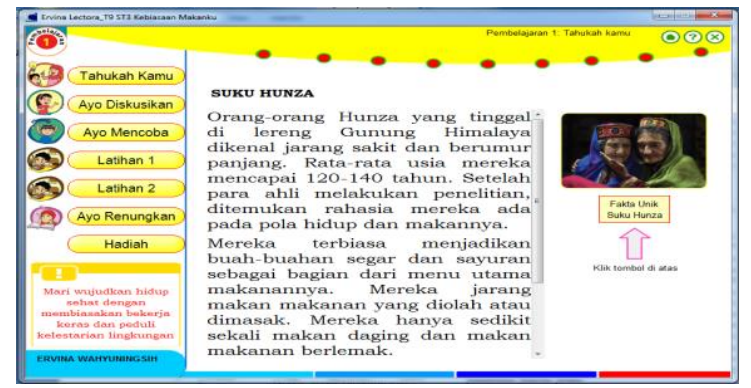

Gambar 5. Slide Multimedia Lectora setelah Direvisi Ahli Produk
Setelah produk direvisi ahli media, produk diujicobakan. Perbaikan multimedia dari hasil uji coba secara umum dari saran pendidik seperti berikut. Pertama, tampilan pada slide menarik minat belajar peserta didik, akan tetapi perintah membuka materi dan penggunaan berbagai tombol dalam multimedia Lectora khususnya pada evaluasi soal sebaiknya diperjelas supaya peserta didik lebih mudah dalam menggunakan multimedia tersebut tanpa bantuan dari pendidik, sehingga peserta didik bisa aktif dan proaktif sendiri dalam mengoperasikan multimedia. Kedua, melalui multimedia Lectora pada pembelajaran tematik integratif sudah sangat membantu dalam membentuk karakter peserta didik akan tetapi akan lebih mencapai indikator pembelajaran lagi jika diberikan contoh yang lebih konkret yang berbentuk video.

Berdasarkan saran guru dari uji coba produk di atas, maka peneliti perjelas kembali pemakaian multimedia dengan disertakannya slide "petunjuk mengerjakan soal" pada menu mengerjakan soal evaluasi di bagian akhir multimedia serta menambahkan video pembelajaran sebagai contoh pada yang nyata dalam pembelajaran. Gambar slide terlihat pada Gambar 6.

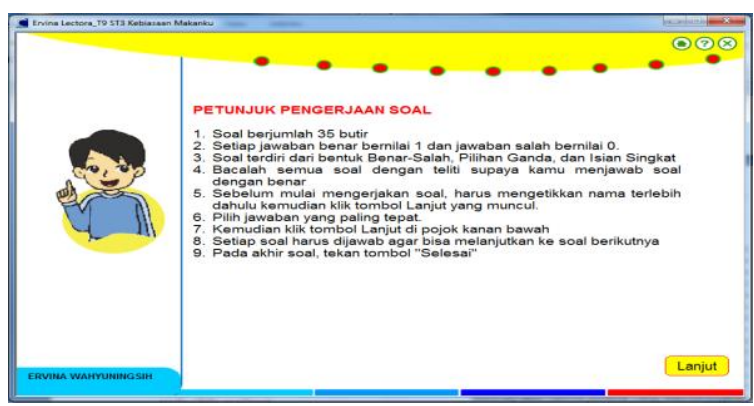

Gambar 6. Gambar Slide Petunjuk Mengerjakan pada Slide Evaluasi

Tambahan slide petunjuk mengerjakan memudahkan peserta didik dalam mengerti peraturan mengerjakan evaluasi soal pembelajaran. Kemudian, saran dari uji 
coba yang kedua yaitu tambahan video pembelajaran yang berfungsi sebagai interpretasi contoh konkret dalam materi, peneliti tambahkan pada pembelajaran 2, 4, dan 5. Slide pembelajaran yang sudah ditambah dengan tampilan video dapat diihat Gambar 7.

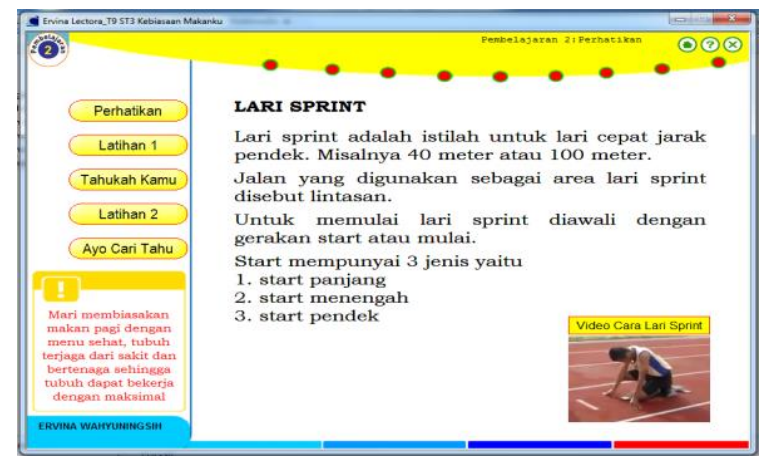

\section{Gambar 7. Gambar Video Lari Sprint} pada Pembelajaran 2

Video "cara lari sprint" pada gambar 7 di atas akan muncul jika user menekan tombol yang berwarna kuning di atas gambar. Tampilan slide pada pembelajaran 4 dan 5 terlihat pada Gambar 8 .

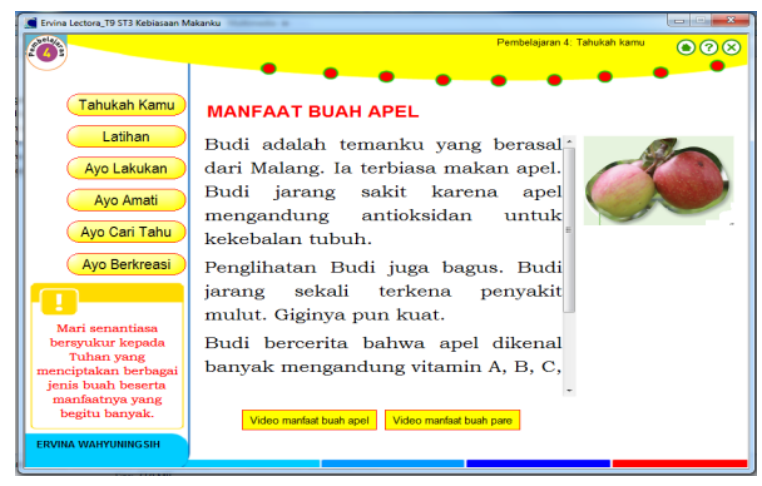

\section{Gambar 8. Video Manfaat Buah Apel \& Pare Pembelajaran 4}

Video akan menyala jika user menekan tombol kuning yang bertuliskan "video manfaat buah apel" dan "video manfaat buah pare". Keberadaan video dalam slide tersebut akan menambah ketertarikan peserta didik dalam belajar lebih tentang mencari manfaat buah di sekitar dan mengaplikasikan manfaat buah tersebut dalam kehidupan sehari-hari mereka. Video yang terakhir, peneliti tambahkan tentang pembuatan hidroponik dari botol bekas. Gambar video terlihat pada Gambar 9.

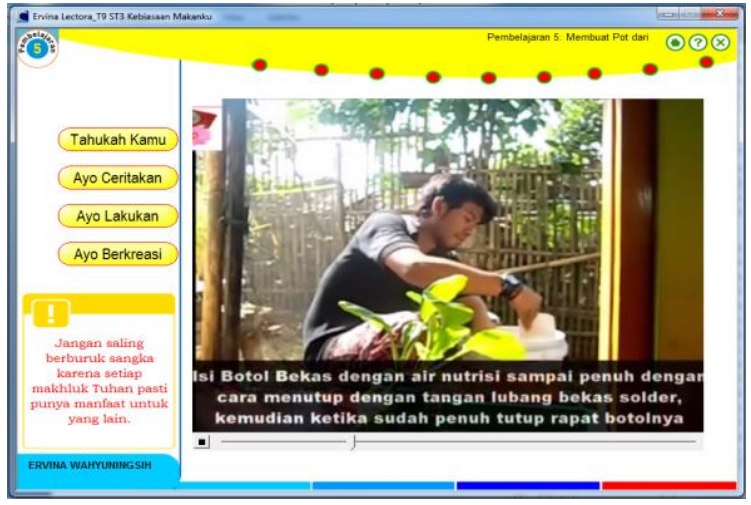

\section{Gambar 9. Video Membuat Hidroponik dari Botol Bekas}

Hasil revisi pada multimedia Lectora akan diujikan kelayakan dan keefektifannya untuk meningkatkan nilai karakter kerja keras dan peduli lingkungan peserta didik dalam pembelajaran tematik integratif pada subtema "Kebiasaan Makanku" kelas IV SDN 03 Jaten Karanganyar.

\section{Kajian Produk Akhir}

Produk akhir berupa multimedia Lectora dalam pembelajaran tematik-integratif pada subtema "Kebiasaan Makanku" untuk meningkatkan nilai karakter kerja keras dan peduli lingkungan kelas IV SDN 03 Jaten Karanganyar. Pengembangan multimedia Lectora pada pembelajaran tematik integratif dengan didukung oleh beberapa program seperti camtasia studio 7, flypaper, dan snagit. Membuat tampilannya agar lebih menarik cukup dengan mempergunakan fasilitas yang sudah dibawa dari program Lectora. Pengembangan media dalam tesis ini berbentuk CD interaktif yang dapat dijalankan di semua komputer dengan spesifikasi minimal processor setara dengan spesifikasi yang sudah dijelaskan diawal. 
Pengembangan produk multimedia Lectora telah dilakukan melalui beberapa tahap, yaitu tahap analisis kebutuhan, tahap pengembangan, tahap validasi, tahap uji coba, dan tahap revisi serta tahap uji efektivitas produk. Hasil uji coba yang dilakukan produk ini telah dinilai layak dan efektif. Kelayakan produk didasarkan pada penilaian ahli. Hasil penilaian ahli menunjukkan bahwa kelayakan produk sangat baik dengan kualitas multimedia pembelajaran dari aspek isi termasuk kategori sangat baik karena ditemukan rerata 4,80. Aspek pembelajaran termasuk kategori sangat baik karena rerata 4,71. Aspek media menunjukkan bahwa kualitas multimedia pembelajaran ini sangat baik karena menunjukkan rerata 4,68. Secara keseluruhan, kualitas pembelajaran ini sangat baik karena ditemukan rerata 4,73 . Oleh karena itu, dapat dikatakan bahwa multimedia ini layak untuk digunakan. Gambar 10 menunjukkan hasil uji dari ahli materi dan ahli media.

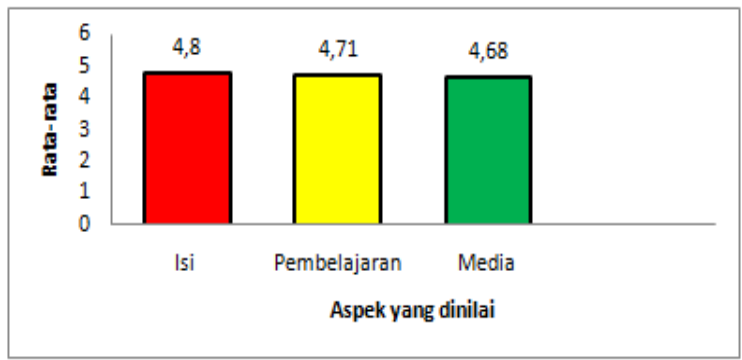

Gambar 10. Diagram Penilaian Uji Kelayakan Produk dari Ahli Materi dan Media

Keefektifan produk diuji dengan menggunakan desain penelitian eksperimen yang dianalisis dengan uji $\mathrm{t}$ "pair sample t-test". Hasilnya menunjukkan bahwa bahwa produk yang dikembangkan efektif meningkatkan nilai karakter kerja keras dan peduli lingkungan peserta didik dengan nilai $\mathrm{t}$ hitung $<\mathrm{t}$ tabel, yaitu $-7,211$ $<-1,710$ pada taraf signifikansi $5 \%$.

Keefektifan produk multimedia yang ditunjukan dengan adanya peningkatan nilai karakter ini disebabkan karena peserta didik melaksanakan pembelajaran tematik-integratif menggunakan multimedia Lectora pada pembelajaran tematik integratif dengan subtema "Kebiasaan Makanku" dengan integrasi nilai karakter di dalamnya. Penggunaan multimedia Lectora yang terintegrasi dengan nilai karakter tersebut berfungsi agar peserta didik dapat bekerja sama secara efektif dalam kegiatan pembelajaran, bekerja tanpa putus asa dan penuh semangat, mempunyai kepedulian terhadap sesama peserta didik dalam proses pemahaman konsep tertentu, terbiasa dalam hidup sehat, dan senantiasa berusaha untuk melestarikan lingkungan. Produk nyata multimedia Lectora yang banyak terintegrasi nilai untuk peserta didik dapat senantiasa bekerja keras dan peduli akan lingkungan, sehingga aplikasi pembelajaran menjadi lebih bermakna dan akan menjadi pengetahuan yang tersimpan dalam memori jangka panjang peserta didik.

\section{PENUTUP}

\section{Simpulan}

Berdasarkan data hasil penelitian dan pengembangan dapat disimpulkan bahwa produk yang dikembangkan berupa multimedia Lectora dalam pembelajaran tematikintegratif pada subtema "Kebiasaan Makanku" untuk meningkatkan nilai karakter peserta didik dinyatakan layak digunakan. Hal ini jika ditinjau dari aspek materi termasuk berkategori sangat baik dengan rerata 4,76. Ahli media termasuk kategori sangat baik dengan rerata 4,68. Tanggapan pendidik terhadap media pembelajaran ini pada uji coba perorangan termasuk dalam kategori sangat baik dengan rerata 4,50 , uji 
coba kelompok kecil dalam kategori sangat baik dengan rerata 4,67 , dan uji coba lapangan juga dalam kategori sangat baik dengan rerata 4,7. Berdasarkan penilaian tersebut, maka media pembelajaran yang dikembangkan layak untuk digunakan pada peserta didik kelas IV di SD Negeri 03 Jaten Karanganyar.

Produk yang dikembangkan juga terbukti efektif berdasarkan hasil uji efektivitas before-after observation rating scale karakter oleh pendidik pada uji lapangan dalam pembelajaran tematik integratif menggunakan multimedia Lectora subtema "Kebiasaan Makanku". Berdasarkan hasil perhitungan didapatkan $75 \%$ peserta didik mengalami peningkatan karakter, sedangkan 25\% mengalami keajekan. Persentase sebesar 75\% apabila diinterpretasikan secara kualitatif dikategorikan efektif karena berada pada rentang $61 \%$ - 80\%. Dilihat dari hasil uji t "paired samples $t$-test" nilai thitung adalah $-7,211$. Nilai $t$ tabel untuk dk 26 pada taraf signifikansi 0,05 adalah -1,71 sampai $+1,71$. Karena nilai $t$ hitung berada di luar daerah penerimaan $\mathrm{H}_{0}$, maka $\mathrm{H}_{0}$ ditolak dan Ha diterima, yaitu ada perbedaan yang signifikan antara nilai rata-rata karakter kerja keras dan peduli lingkungan peserta didik sebelum tindakan dengan nilai ratarata karakter kerja keras dan peduli lingkungan sesudah dilakukan tindakan.

Berdasaarkan data terlihat bahwa rata-rata nilai after pada penilaian karakter lebih tinggi dari rata-rata nilai before. Oleh karena itu, berdasarkan hasil before-after dinyatakan secara signifikan mengalami peningkatan nilai karakter kerja keras dan peduli lingkungan. Oleh karena itu, dapat disimpulkan bahwa multimedia Lectora dalam pembelajaran tematik integratif pada subtema "Kebiasaan Makanku" sangat efektif dalam meningkatkan nilai karakter kerja keras dan peduli lingkungan kelas IV SD 03 Jaten Karanganyar.

\section{Saran}

Saran pemanfaatan produk multimedia Lectora dalam pembelajaran tematik-integratif pada subtema "Kebiasaan Makan$\mathrm{ku}^{\prime}$ " untuk meningkatkan nilai karakter peserta didik kelas IV seperti berikut. Pertama, multimedia Lectora ini sesuai dengan prinsip-prinsip desain pembelajaran dan sesuai dengan silabus model pembelajaran Kurikulum 2013 tematik integratif, serta sudah melalui proses validasi baik oleh ahli materi dan ahli media, maupun peserta didik, maka para guru diharapkan dapat menggunakan produk ini untuk pembelajaran tematik integratif. Kedua, untuk pengembangan lebih lanjut, sebaiknya ditambahkan materi yang belum tercantum dalam multimedia. Ketiga, pengembangan keefektifan produk multimedia ini masih sangat terbatas, disarankan bagi peneliti lain untuk mengembangkan lebih lanjut dan mengkaji lebih jauh tingkat keefektifannya.

\section{DAFTAR PUSTAKA}

Ariani, Niken. 2010. Pembelajaran Multimedia diSekolah. Jakarta: Prestasi Pustaka.

Borg, W.R., \& Gall, M.D. 1983. Educational Research: An Introduction. New York: Longman.

Fanny, A.M \& Suardiman, S.P. 2013. "Pengembangan Multimedia Interaktif untuk Mata Pelajaran Ilmu Pengetahuan Sosial (IPS) Sekolah Dasar Kelas V". Jurnal Prima Edukasia, Vol. 1 (1), pp. 1-10.

Fredy \& Soenarto, S. 2013. Pengembangan "Multimedia Pembelajaran Matema- 
tika pada Materi Bilangan Bulat Kelas IV SDN Lempuyangan I Yogyakarta". Jurnal Prima Edukasia, Vol. 1 (2), pp. 164-175.

Ghuraibeh, N.K. \& Alsmadi, M.A. 2012. "The Impact of Teaching Two Courses (Electronic Curriculum Design and Multimedia) on the Acquisition of Electronic Content Design Skills". The International Journal of Multimedia $\mathcal{E}$ Its Applications (IJMA), 4, 6-8.

Hosnan, M. 2014. Pendekatan Scientific dan Kontekstual dalam Pembelajaran Abad 21. Bogor: Ghalia Indonesia.

Kovalik, S. 2002. "An Extraordinary Time: Teaching in the 21st Century". Jornal of Adventist Education. Vol. 10, pp. 3437.

Mas`ud, M. 2013. Membuat Multimedia Pembelajaran dengan Lectora. Yogyakarta: Pustaka Shonif.

Palopo, K. 2010. “Pengembangan Multimedia Pembelajaran Sains yang Humanistik di Sekolah Dasar". Tesis, tidak Dipublikasikan. Universitas Negeri Yogyakarta.

Peraturan Menteri Pendidikan dan Kebudayaan Nomor 103 Tahun 2014 tentang Pembelajaran pada Pendidikan Dasar dan Pendidikan Menengah.
Prastowo, A. 2011. Panduan Kreatif Membuat Bahan Ajar Inovatif. Yogyakarta: Diva Press.

Sa`ud, U.S. 2008. Inovasi Pendidikan. Bandung: Alfabeta.

Schunk, D. H. 2008. Learning Theories: an Educational Perspective (5 ${ }^{\text {thed). }}$. Upper Saddle River: Pearson.

Sudijono, Anas. 2004. Pengantar Statistik Pendidikan. Jakarta: Raja Grafindo Persada

Sugihartono, et.al. 2007. Psikologi Pendidikan. Yoyakarta: UNY Press.

Sugiyono. 2009. Metode Penelitian Pendidikan: Pendekatan Kuantitatif, Kualitatif dan $R \mathcal{E} D$. Bandung: Alfabeta.

Sukardjo. 2010. Evaluasi Pembelajaran: Buku Pegangan Kuliah. Yogyakarta: PPS UNY.

Sukmadinata \& Nana S. 2008. Metode Penelitian Pendidikan. Bandung: Remaja Rosdakarya.

William, J. D. 2011. How Science Works: Teaching and Learning in the Science Classroom. New York: Continuum Learning in the Science Classroom. 